\title{
Model Pengembangan Lembaga Penyiaran Publik Lokal (LPPL) Radio di Jawa Tengah
}

\author{
Liliek Budiastuti Wiratmo, Noor Irfan, Samudi \\ (liliekbewe@yahoo.com, noor.irfan51@gmail.com, samudi_h@yahoo.com) \\ (Sekolah Tinggi Ilmu Komunikasi Semarang)
}

\begin{abstract}
Local Public Broadcasting radio is broadcasting reform that seeks to restore the sovereignty of the people as the owners of the frequencies through Act No. 32 of 2002 on Broadcasting. Government Regulation No. 11/2005 create the space to Local Government Radio Broadcasting can adjust to the regulations on LPPL Radio. However, up to ten years since the birth of the Broadcasting Act, the presence of LPPL Radio presence in Central Java has not been fully able to show a real role. This study used a qualitative approach through bencmarking studies between LPPL radio with the Broadcasting Licence and the Broadcasting Operation Principle Permit, which is Radio Swara Kendal FM; Radio Kota Batik, Pekalongan; Radio Singosari, Brebes; In FM Radio, Kebumen; Irama FM Radio, Purworejo and LPP RRI Semarang. The result of this research is the Local Public Broadcasting Radio development model accordance with applicable regulations.
\end{abstract}

Keywords: Public Sphere, Local Public Broadcasting, Radio

\section{Pendahuluan}

Lahirnya Undang-undang Nomor 32 tahun 2002 tentang penyiaran membawa perubahan tatanan media penyiaran di Indonesia. Peraturan yang mencakup radio dan televisi tersebut memberi ruang bagi tumbuhnya lembaga penyiaran yang memiliki jalur dan tujuan masing-masing. Menurut pasal 13 ayat (2) Undang-undang yang lahir setelah era reformasi tersebut lembaga penyiaran terdiri dari lembaga penyiaran publik, lembaga penyiaran swasta, lembaga penyiaran komunitas dan lembaga penyiaran berlangganan.

Pada pasal Pasal 14 ayat $1 \mathrm{UU}$ 32/2002 disebutkan: '"Lembaga Penyiaran Publik sebagaimana dimaksud dalam Pasal 13 ayat (2) huruf a adalah lembaga penyiaran yang berbentuk badan hukum yang didirikan oleh negara, bersifat independen, netral, tidak komersial, dan berfungsi memberikan layanan untuk kepentingan masyarakat. Sedangkan pasal yang sama pada ayat (3) Di daerah provinsi, kabupaten, atau kota dapat didirikan Lembaga Penyiaran Publik Lokal.

Pasal 14 UU No 32/2002 tersebut diperkuat dengan Peraturan Pemerintah Nomor 11 tahun 2005 tentang Lembaga Penyiaran Publik. Pasal 1 ayat (3) PP menyebutkan: "Lembaga Penyiaran Publik Lokal adalah lembaga penyiaran yang berbentuk badan hukum yang didirikan oleh pemerintah daerah, menyelenggarakan kegiatan penyiaran radio atau penyiaran televisi, bersifat independen, netral, tidak komersial, dan berfungsi memberikan layanan untuk kepentingan masyarakat yang siarannya berjaringan dengan Radio Republik Indonesia (LPP RRI) untuk radio dan Televisi Republik Indonesia (TVRI) untuk televisi.

$$
\text { Melalui UU 32/2002 dan PP } 11
$$
tahun 2005 tersebut pemerintah berusaha memberi peluang bagi Radio Siaran Pemerintah Daerah (RSPD) atau Radio Khusus Pemerintah Daerah (RKPD) untuk menyesuaikan dengan UU Penyiaran, dan dapat menjalankan 
fungsi dan peran strategisnya dengan baik. Sebagai radio yang memanfaatkan dana publik melalui APBD dan pengelolaannya melibatkan publik memiliki posisi strategis bagi terciptanya demokratisasi penyiaran.

$$
\text { Sementara itu, Lembaga }
$$

Penyiaran Publik (Public Broadcasting) atau dikenal juga dengan sebutan Public Servive Broadcasting (PBS) adalah penyiaran dibuat, dibiayai dan dikontrol oleh publik, untuk publik. Hal ini tidak komersial maupun milik negara, bebas dari campur tangan politik dan tekanan dari kekuatan komersial (iklan). (http://portal.unesco.org/ci/en/ev.phpURL_ID $=1525 \& U R L \_D O=D O$ TOPIC\& URL_SECTION=201.html)

LPP pertama kali lahir di Inggris pada awal 1932 saat BBC merambah dunia pertelevisian. BBC yang semula merupakan penyiaran radio yang berdiri tahun 1922 oleh Charles Reith. Dalam 16 tahun kepemimpinannya Reith mampu mengubah BBC menjadi salah satu institusi yang dihormati di Inggris, dan mendapat dukungan penuh dari publik melalui uang langganan. Sedangkan lembaga Penyiaran Publik di Amerika Serikat dimulai saat Presiden Lyndon B. Johnson (1908-1973) meresmikan The Public Broadcasting Act sebagai Undang-undang pada tanggal 7 November 1967. (http://www.enotes.com/history-factfinder/culture-recreation/when-waspublic-broadcasting-founded).

$$
\text { Model Public Service }
$$

Broadcasting Law (Werner Rumphorst, 1998) memberi batasan, Penyiaran publik adalah sebuah konsep unik. Meskipun mudah dimengerti, tetapi lebih sering daripada tidak disalahpahami, kadang-kadang sangat, kadang-kadang bahkan sengaja. Beberapa bahasa bahkan tidak memiliki istilah yang benar-benar sesuai dengan kata Inggris "publik", dan terjemahan terdekat muncul dari negara/pemerintah/badan resmi. Ini sering terjadi di negara yang telah memiliki tradisi penyiaran negara, hambatan linguistik menjadi perintang pertama untuk memahami dengan baik sifat sesungguhnya LPP (Banerjee dan Seneviratne, 2005).

Selanjutnya berbagai negara mengembangkan LPP sebagai upaya memberi hak atas frekuensi sebagai wilayah publik (public sphere). Di Indonesia LLP mulai dikenal setelah lahirnya UU 32 tahun 2002 tentang Penyiaran. Pada pasal 14 ayat (3) UU tersebut dikatakan "Di daerah provinsi, kabupaten, atau kota dapat didirikan Lembaga Penyiaran Publik lokal.”

UNDP (2004) mengemukakan perbedaan LPP dengan lembaga penyiaran yang dikelola negara dan lembaga penyiaran swasta, baik dari sisi definisi, landasan operasional, posisi audiens derta sumber dana yang digunakan untuk mengelola masingmasing lembaga penyiaran tersebut. 
Tabel 1

\section{Different Broadcasting Models}

\begin{tabular}{|c|c|c|c|}
\hline Type & State & Public Service & $\begin{array}{c}\text { Commer } \\
\text { cial }\end{array}$ \\
\hline $\begin{array}{l}\text { Des- } \\
\text { cripti- } \\
\text { on }\end{array}$ & $\begin{array}{l}\text { State authorities } \\
\text { directly } \\
\text { supervise the } \\
\text { media system } \\
\text { and have full } \\
\text { control over } \\
\text { content/ } \\
\text { programming }\end{array}$ & $\begin{array}{l}\text { The media system is } \\
\text { defined through a } \\
\text { carefully aryiculated } \\
\text { legislative framework in } \\
\text { which the media is in } \\
\text { public hands but } \\
\text { management/operations } \\
\text { enjoy subtantial } \\
\text { programming autonomy }\end{array}$ & $\begin{array}{l}\text { Private } \\
\text { owner- } \\
\text { ship } \\
\text { usually } \\
\text { accom- } \\
\text { panied by } \\
\text { some } \\
\text { degree of } \\
\text { state } \\
\text { regula- } \\
\text { tion }\end{array}$ \\
\hline $\begin{array}{l}\text { Opra- } \\
\text { ting } \\
\text { Ratio- } \\
\text { nale }\end{array}$ & $\begin{array}{l}\text { Programming } \\
\text { driven by } \\
\text { political } \\
\text { interests }\end{array}$ & $\begin{array}{l}\text { Programming driven by } \\
\text { public intersts }\end{array}$ & $\begin{array}{l}\text { Program- } \\
\text { ming } \\
\text { driven by } \\
\text { commer- } \\
\text { cial } \\
\text { interests }\end{array}$ \\
\hline $\begin{array}{l}\text { The } \\
\text { Audi- } \\
\text { ence }\end{array}$ & Citizens & Citizens & $\begin{array}{l}\text { Consu- } \\
\text { mers }\end{array}$ \\
\hline $\begin{array}{l}\text { Re- } \\
\text { venue } \\
\text { So- } \\
\text { urces }\end{array}$ & Taxes & $\begin{array}{l}\text { Subcription fees from } \\
\text { viewers/listeners; state } \\
\text { funding; small amount of } \\
\text { advertising }\end{array}$ & $\begin{array}{l}\text { Adver- } \\
\text { tising; } \\
\text { Private } \\
\text { invest- } \\
\text { ment }\end{array}$ \\
\hline
\end{tabular}

Toby Mendel (2000)

mengemukakan tiga syarat penyiaran publik agar dapat tumbuh sebagaimana mestinya:

1. Kemandirian penyiaran publik harus dijamin melalui struktur yang layak seperti badan pelaksana yang pluralistik dan mandiri.

2. Harus dijamin pendanaannya sehingga mencukupi untuk melayani kebutuhan dan kepentingan publik

3. Harus memiliki pertanggungjawaban langsung kepada publik, khususnya dalam hal pelaksanaan misi mereka dan juga pengunaan sumber daya publik.

Badan dunia United Nations Educational, Scientific and Cultural Organization (UNESCO) memandang LPP memiliki peran penting dalam menyediakan akses dan partisipasi dalam kehidupan publik. Terutama di negara berkembang, PSB dapat berperan dalam mempromosikan akses ke pendidikan dan kebudayaan, mengembangkan pengetahuan, dan mendorong interaksi antara warga negara. Bagi sebagian besar penduduk dunia, terdiri dari penduduk wilayah pedesaan yang sangat besar dan orangorang buta huruf, radio dan televisi tetap TIK yang paling tersedia dan luas, dengan radio di tempat pertama sebagai media komunikasi utama. UNESCO telah berkomitmen untuk mendukung dan mempromosikan penyiaran publik serta pelestarian isinya yang melayani kepentingan rakyat sebagai warga negara bukan sebagai konsumen, dengan mencapai semua populasi dan kelompok tertentu dan dengan demikian kontribusi terhadap inklusi sosial dan penguatan masyarakat sipil. Strategi UNESCO "berusaha untuk meningkatkan peran lembaga penyiaran publik sebagai layanan unik menyediakan akses universal terhadap informasi dan pengetahuan melalui beragam konten yang berkualitas dan mencerminkan kebutuhan, keprihatinan dan harapan dari berbagai sasaran." (Banerjee dan Seneviratne, 2005)

Keberadaan LPP sebagai ruang publik (public sphere) memiliki peran penting, yang memberi ruang bagi publik untuk bersama-sama belajar memahami satu sama lain, menyemaikan sengangat kemajemukan. Unesco (Khan, 2006) menggambarkan betapa pentingnya LPP bagi rakyat. Ia adalah media penyemangat rakyat dan tinggal bersama dan untuk rakyat dalam kehidupan yang kian kompleks.

$\begin{array}{clr}\text { UNESCO } & \text { dalam } & \text { Public } \\ \text { broadcasting: } & \text { Why? } & \text { How? }\end{array}$
menekankan, bukan alasan komersial atau kontrol Negara, penyiaran publik hanya dikendalikan semata-mata pelayanan publik. Ini adalah organisasi penyiaran milik publik, yang berbicara kepada semua orang sebagai warga 
negara. Lembaga penyiaran publik mendorong akses dan partisipasi dalam kehidupan publik. Mereka mengembangkan pengetahuan, memperluas wawasan dan memungkinkan orang untuk lebih memahami diri, dunia dan lain-lain dengan pemahaman yang lebih baik.

Penyiaran publik didefinisikan sebagai tempat pertemuan di mana semua warga menyambut baik dan dianggap sama. Ini adalah informasi dan alat pendidikan, dapat diakses oleh semua dan dimaksudkan untuk semua, apapun status sosial atau ekonomi. Mandatnya tidak terbatas pada informasi dan penyiaran publik, pengembangan budaya juga harus menarik imajinasi, dan menghibur. Tetapi ia melakukannya dengan perhatian untuk kualitas yang membedakannya dari penyiaran komersial.

Karena tidak didikte profitabilitas, penyiaran publik harus berani, inovatif, dan mengambil risiko. Dan ketika berhasil mengembangkan genre atau ide, itu dapat menjadi standar yang tinggi dan dapat mengatur irama lembaga penyiaran lain. Untuk beberapa, seperti penulis Inggris Anthony Smith, menulis tentang British Broadcasting Corporation-dilihat oleh banyak orang sebagai tempat lahir penyiaran-publik begitu penting yang telah "mungkin menjadi yang terbesar dari instrumen demokrasi sosial abad ini (Banerjee dan Seneviratne, 2005).

Lalu, LPPL Radio dapat diumpamakan sebagai 'taman penyiaran' (Wiratmo, 2005) menjadi tempat bertemunya berbagai kepentingan dan lapisan masyarakat. Sebagai bentuk fasilitas umum (fasum) di udara untuk memberi kenyamanan bagi publik yang kepentingannya tak terwakili oleh media arus utama (media mainstream). Namun hingga kini dan masih panjang waktu yang diperlukan untuk mewujudkannya. Mengacu pada UU 32/2002 perlu ketelibatan Publik, Pemerintah Daerah dan DPRD untuk menjamin keberhasilan sebuah LPP.

Keberadaan LPPL diperkuat dengan Peraturan Pemerintah Nomor 11 tahun 2005 tentang Lembaga Penyiaran Publik. Berikut kutipan beberapa pasal yang berkaitan dengan LPP Lokal. Pasal 4: LPP RRI, TVRI, dan Lembaga Penyiaran Publik Lokal bertujuan menyajikan program siaran yang mendorong terwujudnya sikap mental masyarakat yang beriman dan bertakwa, cerdas, memperkukuh integrasi nasional dalam rangka membangun masyarakat mandiri, demokratis, adil dan sejahtera, serta menjaga citra positif bangsa.

Pasal 6

(1) Lembaga Penyiaran Publik Lokal menyelenggarakan kegiatan siaran lokal.

(2) Untuk menunjang peningkatan kualitas operasional penyiaran, Lembaga Penyiaran Publik Lokal dapat menyelenggarakan kegiatan siaran iklan dan usaha lain yang sah yang terkait dengan penyelenggaraan penyiaran.

Pasal 7

(1) Lembaga Penyiaran Publik Lokal merupakan lembaga penyiaran yang berbentuk badan hukum yang didirikan oleh pemerintah daerah dengan persetujuan Dewan Perwakilan Rakyat Daerah atas usul masyarakat.

(2) Lembaga Penyiaran Publik lokal sebagaimana dimaksud pada ayat (3) dapat didirikan di daerah provinsi, kabupaten, atau kota dengan kriteria dan persyaratan sebagai berikut : 
a. belum ada stasiun penyiaran LPP RRI dan/atau TVRI di daerah tersebut;

b. tersedianya alokasi frekuensi;

c. tersedianya sumber daya manusia yang profesional dan sumber daya lainnya sehingga Lembaga Penyiaran Publik lokal mampu melakukan paling sedikit 12 (dua belas) jam siaran per hari untuk radio dan 3 (tiga) jam siaran per hari untuk televisi dengan materi siaran yang proporsional;

d. operasional

siaran

diselenggarakan

secara

berkesinambungan.

(3) Lembaga Penyiaran Publik lokal yang telah beroperasi sebelum stasiun penyiaran LPP RRI dan/atau TVRI didirikan di daerah layanan siaran Lembaga Penyiaran Publik Lokal tersebut, tetap dapat melaksanakan operasinya.

(4) Lembaga Penyiaran Publik Lokal dapat bekerjasama hanya dengan LPP RRI untuk Lembaga Penyiaran Publik Lokal radio, dan dengan TVRI untuk Lembaga Penyiaran Publik Lokal televisi.

$\begin{array}{ccc}\text { Meski } & \text { aturan tersebut telah } \\ \text { memberi } & \text { ruang } & \text { bagi }\end{array}$

RSPD/RKPD/Struda (Sudibyo, 2004) untuk menyesuaikan dengan aturan baru, namun pada kenyataannya tidaklah mudah. Selain persoalan mindset tentang radio milik pemerintah, juga adanya tuntutan PAD terhadap radio yang dikelola pemerintah daerah tersebut. Tuntutan untuk pemasukan PAD mendorong lembaga penyiaran yang menggunakan dana APBD tersebut melakukan langkah instan. Agus Sudibyo (2004) mencatat muncul juga era dimana pemerintah daerah melakukan swastanisasi radio pemerintah daerah tersebut dengan menggunakan nama seolah radio swasta. Swastanisasi dilakukan dengan secara internal, dimana direktur, manajer dll adalah pejabat pemerintah daerah. Modus lain adalah pengelola eksternal, yang melibatkan pengusaha radio swasta. Ia menemukan di Jawa Tengah ada beberapa RSPD yang dikelola pihak ketiga, yaitu RSPD Jepara, Pekalongan, Kudus, Pati, Salatiga, Magelang dan Purworejo yang tergabung dalam CPP Radio Net.

Era ini menandai masuknya era mencari keuntungan dan di kemudian hari menjadi senjata ampuh bagi pembuat kebijakan untuk menantang pengelola radio untuk memasukkan sejumlah dana dalam bentuk Pendapatan Asli Daerah (PAD) bila ingin memperoleh dana APBD.

Bila tawar menawar antara anggaran yang dialokasikan untuk LPPL Radio dan jumlah PAD yang harus disetor masih mengemuka, maka tujuan utama LPPL Radio tidak akan tercapai. Sedangkan pandangan UNDP (2004) jelas, bahwa tujuan utama lembaga penyiaran publik adalah untuk menyediakan siaran berkualitas yang memenuhi kebutuhan informais, hiburan dan pendidikan dari masyarakat sekaligus juga menghormati dan menjunjung kemajemukan. Kepuasan pencapaian tujuan ini tidak akan mungin tercapai bila penyiaran publik diharapkan untuk mencari dana seperti pernyiaran komersial lain. Ketergantungan komersial akhirnya akan membuat para penyiar publik meletakkan produksi program dan mengambil penjadwalan sebagai ujian popularitas dan bukannya mengambil keputusan untuk kepentingan masyarakat. 


\section{Metodologi Penelitian}

Penelitian ini menggunakan studi benchmarking untuk mengetahui dan menemukan aspek-aspek unggul dan positif untuk membangun model

\begin{tabular}{|c|l|l|l|}
\hline No. & \multicolumn{1}{|c|}{$\begin{array}{c}\text { Nama } \\
\text { Lembaga } \\
\text { Penyiaran }\end{array}$} & \multicolumn{1}{|c|}{ Alamat } & Kab/Kota \\
\hline 1. & $\begin{array}{l}\text { LPPL Radio } \\
\text { Irama FM Kendal }\end{array}$ & $\begin{array}{l}\text { Jl. Kyai } \\
\text { Gembyang } \\
\text { No. 1 Kendal }\end{array}$ & $\begin{array}{l}\text { Kab. } \\
\text { Kendal }\end{array}$ \\
\hline 2. & $\begin{array}{l}\text { LPPL Radio Kota } \\
\text { Batik }\end{array}$ & $\begin{array}{l}\text { Jl. Kurinci } \\
\text { No. } ~ \\
\text { Pekalongan }\end{array}$ & $\begin{array}{l}\text { Kota } \\
\text { Pekalongan }\end{array}$ \\
\hline 3. & $\begin{array}{l}\text { LPPL Radio } \\
\text { Singosari }\end{array}$ & $\begin{array}{l}\text { Jl. Veteran } \\
\text { No. 14 } \\
\text { Brebes }\end{array}$ & $\begin{array}{l}\text { Kab. } \\
\text { Brebes }\end{array}$ \\
\hline 4. & $\begin{array}{l}\text { LPPL Radio In } \\
\text { FM }\end{array}$ & $\begin{array}{l}\text { Jl. Kutoarjo } \\
\text { No. 6 } \\
\text { Kebumen }\end{array}$ & $\begin{array}{l}\text { Kab. } \\
\text { Kebumen }\end{array}$ \\
\hline 5. & $\begin{array}{l}\text { LPPL Radio } \\
\text { Irama FM }\end{array}$ & $\begin{array}{l}\text { Jl. A. Yani } \\
\text { No. 13 } \\
\text { Purworejo }\end{array}$ & $\begin{array}{l}\text { Kab. } \\
\text { Purworejo }\end{array}$ \\
\hline 6. & $\begin{array}{l}\text { LPP RRI } \\
\text { Semarang } \\
\text { (sebagai } \\
\text { benchmark })\end{array}$ & $\begin{array}{l}\text { Jl. Ahmad } \\
\text { Yani 144-146 } \\
\text { Semarang }\end{array}$ & $\begin{array}{l}\text { Kota } \\
\text { Semarang }\end{array}$ \\
\hline
\end{tabular}

pengembangan LPPL radio di Jawa Tengah.

Dalam konteks penelitian ini keberadaan LPPL Radio tak dapat dipisahkan dari aturan yang menaungi, kepekaan pengambil kebijakan, pengelolaan organisasi dan sumberdaya manusia, pendanaan, serta keterlibatan stakeholder secara keseluruhan termasuk publik penerima siarannya.

Pada tahap awal di tahun pertama (Wiratmo, Irfan, 2012) dilakukan pemetaan persoalan yang dihadapi pengelola LPPL Radio di Jawa Tengah melalui pembandingan (benchmarking) antar stasiun yang belum belum memproses perijinan sebagai jalan masuk untuk memahami keseluruhan persoalan. Melalui pemetaan ini akan ditemukan berbagai faktor kekuatan, kelemahan, peluang, dan tantangan yang dihadapi pengelola LPPL Radio sebagai ujung tombak keberhasilan. Selain itu juga dapat diformulasikan faktor-faktor pendorong untuk mengembangkan LPPL Radio di Jawa Tengah.
Hasil penelitian tahap pertama dilanjutkan tahun kedua, yaitu melakukan kajian melalui benchmarking fungsional antar LPPL Radio yang telah mencapai tahap IPPP dan IPP. Langkah ini ditempuh dengan asumsi setiap LPPL Radio memiliki nilai positif dan keunggulan yang dapat dikembangkan LPPL radio yang lain. Lembaga Penyiaran Publik LPP RRI Semarang sebagai model utama pengembangan karena lembaga ini mempunyai payung hukum yang kuat serta langkah-langkah maju yang dapat diadaptasi oleh LPPL radio sebagaimana dikatakan oleh Deming (Watson, 1996) bahwa tujuan benchmarking adalah adaptasi, bukan adopsi."

\section{Hasil dan Pembahasan}

Dalam penelitian tahun pertama diperoleh beberapa termuan adanya 'kegagapan' pemerintah daerah dalam menyikapi Undang-Undang Penyiaran No. 32 tentang Penyiaran, Bagian Keempat, tentang Lembaga Penyiaran Publik. Kegagapan tersebut menimbulkan efek dalam proses perijinan LPPL radio.

Sejak keluarnya UU penyiaran hingga tahun pertama penelitian ini baru ada satu LPPL radio yang sudah memiliki Izin Penyelenggaran Penyiaran (IPP), LPPL radio Buana Asri Sragen. Hal ini disebabkan: Pertama, belum diterbitkannya Peraturan Daerah (Perda) tentang LPPL radio oleh kepala daerah bersama DPRD. Hal ini terjadi karena ketidakpahaman dan kebingungan eksekutif dan legislatif tentang bentuk badan hukum LPPL radio. (dapat dilihat dalam laporan tahun I hal 31). Kedua, beragamnya penempatan RSPD dalam SOTK Pemerintahan Daerah. Ada yang berada dibawah Dinas Perhubungan dan 
Komunikasi Informasi, ada yang berada dibawah humas di sekretariat daerah. Hal ini dikarenakan keraguan tentang payung hukum yang bisa dijadikan acuan untuk menempatkan LPPL Radio sebagai lembaga publik yang mandiri diluar organisasi Pemerintah Daerah. (dapat dilihat di laporan tahun I hal 23) Ketiga, Keragaman penempatan dalam SOTK RSPD/LPPL Radio tersebut menjadikan keraguan dalam penentuan pos anggaran daerah. Sehingga hal ini mempersulit pelaksanaan amanat UU Penyiaran bahwa RSPD/LPPL Radio dapat menggunakan dana APBD. (dapat dilihat di laporan tahun I hal 25). Keempat, belum melibatkan publik dalam pengelolaan LPPL maupun program acaranya.

Pada penelitian tahun kedua yang diarahkan kepada LPPL Radio yang sudah mempunyai ijin minimal IP3 dan LPP RRI Semarang sebagai LPPL Radio pembanding. Dari penelitian lapangan tahun kedua diperoleh beberapa temuan: pertama, keberhasilan mereka memperoleh perijinan lebih dikarenakan keberanian dan komitmen pimpinan daerah (Bupati/Walikota) bersama DPRD dalam mentransformasi RSPD menjadi LPPL radio. Kedua, dari lima obyek penelitian empat diantaranya telah menempatkan LPPL radio sebagai lembaga diluar pemerintah dearah, sedang satu diantaranya (Irama FM Purworejo) dalam Satuan Organisasi dan Tata Kerja masih menempatkan LPPL radio sebagai Unit Pelaksana Tugas di bawah Dishubkominfo. Dari empat radio yang menempatkan LPPL dlluar organisasi Pemerintah Daerah, baru satu LPPL (Radio Kota batik Pekalongan) yang benar-benar melepas secara mandiri yaitu dengan mengisi pengelola radio dari karyawan non pegawai negeri sipil (PNS). Hal ini menunjukkan bahwa secara kelembagaan masih terdapat keraguan dalam pembentukan LPPL radio sebagai suatu Badan Hukum Lembaga Penyiaran Publik yang independen. Ketiga, dalam masalah pengelolaan anggaran, kelima obyek penelitian telah memiliki pos serta rekening anggaran yang jelas dalam SKPD yang dijadikan induknya. Dua radio tidak membebani LPPL radio dengan PAD, dan satu radio (Swara Kendal) yang memberikan kebebasan LPPL radio untuk mengelola pendapatan keuangannya sendiri tanpa kewajiban menyetorkan ke Kas Daerah. Ini menunjukkan bahwa masih ada keraguan dalam sistem pengelolaan keuangan LPPL Radio. Keempat, dari wawancara dengan pengelola LPPL radio sangat mengharapkan agar LPPL radio menjadi badan layanan umum daerah untuk mempermudah pengelolaan anggarannya. Atau ingin menjadi LPPL sebagaimana Radio Republik Indonesia (RRI). Kelima, dari kelima LPPL yang sudah mengantongi ijin ini ternyata juga belum melibatkan publik secara langsung dalam pengelolaan program-program siarannya.

Temuan-temuan sebagaimana di atas yang menjadi landasan dalam menyusun model sebagai solusi pemecahan dalam pengembangan LPPL radio.

\section{Kelembagaan LPPL Radio}

Dalam Undang-Undang Penyiaran No. 32 Tahun 2002, Pasal 14 (1) disebutkan: Lembaga Penyiaran Publik adalah lembaga penyiaran yang berbentuk badan hukum yang didirikan oleh negara, bersifat independen, netral, tidak komersial, dan berfungsi memberikan layanan untuk kepentingan masyarakat. Pasal 14 (3) Di daerah provinsi, kabupaten, atau kota dapat 
didirikan Lembaga Penyiaran Publik Lokal.

Peraturan Pemerintah Nomor 11 tahun 2005 tentang Lembaga Penyiaran Publik. Pasal 7 (3) Lembaga Penyiaran Publik Lokal merupakan lembaga penyiaran yang berbentuk badan hukum yang didirikan oleh pemerintah daerah dengan persetujuan Dewan Perwakilan Rakyat Daerah atas usul masyarakat.

Mengacu pada peraturan perundang-undangan dan peraturan pemerintah di atas, secara jelas disebutkan bahwa LPPL radio adalah Badan Hukum yang didirikan oleh negara dalam hal ini pemerintah Daerah dengan persetujuan DPRD, bersifat independen, netral, tidak komersial.

Berpedoman kedua peraturan ini mestinya tidak perlu ada keraguan lagi bagi pemerintah daerah untuk mentarnsformasi RSPD menjadi LPPL radio. Hampir di semua daerah tingkat II di Jawa Tengah sebelum lahirnya UU 32/2002 telah memiliki RSPD, sehingga memiliki LPPL radio yang harus dilakukan adalah mentransformasi RSPD yang semula berada di bawah SOTK pemerintah daerah menjadi lembaga yang berada diluar struktur melalui perda yang dibuat Pemda bersama DPRD.

Bila dikaji, semangat lahirnya UU 32/2004 bagian ke empat tentang LPPL dimaksudkan untuk menjaga kemandirian LPPL sebagai lembaga hukum pelayanan informasi kepada publik. Kedudukan LPPL radio yang tidak berada dibawah SOTK Pemerintah Daerah baik sebagai Unit Pelaksana Tugas, atau Unit kerja di bawah dinas atau bagian akan mengurangi campur tangan pemerintah dalam pengelolaan LPPL. Demikian pula sebagai lembaga di luar organisasi Pemerintah Daerah selayaknya kalau pelaksana LPPL radio juga bukan PNS. Sedangkan benang merah antara Pemerintah Daerah dengan LPPL radio ada pada Dewan Pengawas. Dewan Pengawas sebagaimana disebutkan dalam PP No. 11 Tahun 2005 pasal 1 ayat 5, merupakan organ LPP yang berfungsi mewakili masyarakat, pemerintah dan unsur lembaga penyiaran publik dan bertugas menjalankan pengawasan untuk mencapai tujuan lembaga penyiaran publik.

\section{Pengelolaan Anggaran}

Masalah anggaran LPPL Radio, dari temuan penelitian selama dua tahun dapat dikatakan merupakan "dilema LPPL". Hal ini karena dalam undangundang dan peraturan pemerintah tidak secara jelas menyebutkan bentuk badan hukum LPPL. Pasal 15 UU 32/2002 ayat (1) Sumber pembiayaan Lembaga Penyiaran Publik berasal dari:
a. Iuran penyiaran;
b. Anggaran Pendapatan dan Belanja Negara atau Anggaran Pendapatan dan Belanja Daerah; sumbangan masyarakat;
c. siaran iklan; dan
d. usaha lain yang sah yang terkait dengan penyelenggaraan penyiaran

Pasal 15 UU 32/2002 Ayat (2): "Setiap akhir tahun anggaran, Lembaga Penyiaran Publik wajib membuat laporan keuangan yang diaudit oleh akuntan publik dan hasilnya diumumkan melalui media massa."

Sebagai penjabaran lebih lanjut dari UU 32/2002, pada pasal 14 Peraturan Pemerintah Nomor 11 tahun 2005 tentang Lembaga Penyiaran Publik tercantum:

Ayat (1) Sumber pembiayaan RRI, TVRI, dan Lembaga Penyiaran Publik Lokal berasal dari: 
a. Iuran penyiaran

b. Anggaran Pendapatan dan Belanja Negara atau Anggaran Pendapatan dan Belanja Daerah

c. Sumbangan Masyarakat

d. Siaran Iklan

e. Usaha lain yang sah yang terkait dengan penyelenggaraan penyiaran

Ayat (2) Penerimaan yang diperoleh dari sumber pembiayaan sebagaimana dimaksud pada ayat (1) huruf a, huruf $\mathrm{c}$, huruf $\mathrm{d}$, dan huruf $\mathrm{e}$ merupakan penerimaan negara yang dikelola langsung secara transparan untuk membiayai Lembaga Penyiaran Publik sesuai dengan ketentuan peraturan perundang-undangan yang berlaku.

Peraturan Pemerintah tentang pembiayaan dan pengelolaan keuangan LPPL Radio sebagai termaktub dalam pasal 14 (2) di atas, menunjukkan bahwa ada kemandirian dalam pengelolaan keuangan LPPL radio. Dalam struktur anggaran LPPL radio mempunyai dua sumber penerimaan utama, sumber APBD dan sumber penerimaan di luar APBD yaitu iklan dan usaha lain yang sah yang terkait dengan penyelenggaran penyiaran. Penerimaan LPPL radio yang berasal dari luar APBD dengan berpedoman pada aturan ini seharusnya dapat dikelola langsung tanpa harus disetor ke Kas Daerah sebagai penerimaan daerah.

Namun bila melihat bahwa LPPL Radio tersebut menggunakan aset daerah dan mendapatkan pembiayaan dari APBD maka hal ini akan bertentangan dengan amanat dalam Undang-Undang Nomor 17 tahun 2003 tentang Keuangan Negara. Dalam pasal 2 point g UU itu disebutkan: "kekayaan negara/kekayaan daerah yang dikelola sendiri atau oleh pihak lain berupa uang, surat berharga, piutang, barang, serta hak-hak yang dapat dinilai dengan uang termasuk kekayaan yang dipisahkan pada perusahaan negara/perusaan daerah adalah bagian dari Keuangan Nerara." Selanjutnya pada pasal 3 (7): "semua penerimaan yang menjadi hak dan pengeluaran yang menjadi kewajiban daerah dalam tahun anggaran yang bersangkutan harus dimasukkan dalam APBD."

Bila mengacu UU 17 tahun 2003 tersebut, sebagai lembaga bentukan pemerintah daerah yang masih menggunakan aset maupun anggaran dari pemerintah daerah, maka LPPL bisa dikategorikan sebagai kekayaan daerah. Maka semua penerimaan dan pengeluarannya harus masuk dalam APBD.

Benturan dua undang-undang (UU Penyiaran dan UU Keuangan Negara) ini yang menjadikan keraguan pemerintah daerah dan pengelola LPPL dalam meyikapi pengelolaan keuangan. Ada sebagian yang memilih "aman" dengan tetap menyetorkan penerimaan diluar APBD sebagai penerimaan daerah, ada sebagaian yang berani memberikan kewenangan pengelolaan penerimaan non APBD kepada pengelola LPPL radio.

Untuk mencari jalan keluar dari benturan dua peraturan di atas peneliti menawarkan menggunakan PP No. 23/2005 tentang pengelolaan Keuangan Badan Layanan Umum sebagai model pengelolaan keuangan LPPL Radio. Dalam pasal 1 ayat (1) PP 23/2005 disebutkan: Badan Layanan Umum yang selanjutnya disingkat BLUD adalah Satuan Kerja Perangkat Daerah atau Unit Kerja pada Satuan Kerja Perangkat Daerah di lingkungan pemerintah daerah yang dibentuk untuk memberikan pelayanan kepada masyarakat berupa penyediaan barang 
dan/atau jasa yang dijual tanpa mengutamakan mencari keuntungan, dan dalam melakukan kegiatannya didasarkan pada prinsip efisiensi dan produktivitas.

Hal ini dibenarkan oleh Prof. DR. Yos Johan Utama, SH.Mhum. dari Fakultas Hukum Universitas Diponegoro sebagai verifikator ahli dalam penelitian ini. Dikatakan bahwa paling tepat untuk LPPL Radio bila menggunakan Pola Pengelolaan Keuangan Badan Layanan Umum (PPK-BLU). Karena kalau LPPL Radio tidak ditetapkan sebagai BLUD maka tetap tidak dapat mengelola keuangan secara mandiri karena terbentur UU 17/2003 tentang Keuangan Negara.

Bila dilihat dari fungsi LPPL Radio sebagai pelayan informasi publik maka LPPL radio memenuhi persyaratan substantif penetapan sebagai BLUD seperti dimaksud dalam BAB III pasal 4 (2) PP 23/2005, dimana satuan kerja dapat ditetapkan sebagai BLU bila yang bersangkutan menyelenggarakan layanan umum yang berhubungan dengan penyediaan barang dan/atau jasa layanan umum.

Pilihan ini mungkin bukan yang terbaik dan tidak sesuai dengan semangat lahirnya UU 32/2002 yang ingin menempatkan lembaga penyiaran publik sebagai sebuah lembaga yang sepenuhnya independen sebagaimana lembaga penyiaran publik telah berkembang di negara lain. Hal ini sebagaimana diungkapkan Prof. Yos Johan Utama,SH.Mhum., pada saat verifikasi penelitian ini, yang menyatakan bahwa selama masih ada dana APBN/APBD dan aset yang digunakan LPPL Radio milik negara maka pengelolaannya harus tunduk pada aturan yang berlaku. Di sisi lain kepentingan publik tak boleh diabaikan. Dengan demikian pengelolaan keuangan LPPL radio sebagai BULD adalah pilihan tengah yang menjadi titik temu agar tak merugikan kepentingan publik

Bentuk independensi LPPL Radio diwujudkan melalui personil penyelenggara berasal dari luar instansi pemerintah dan bertanggung jawab kepada Dewan Pengawas yang terdiri dari berbagai unsur. Kontrol terhadap independensi konten siaran selain kontrol internal juga kontrol langsung dari masyarakat maupun regulator penyiaran. Kondisi yang kini sangat terbuka dan demokratis memungkinkan kontrol eksternal berjalan baik. Hal ini sangat berbeda dengan di masa lalu saat kontrol pemerintah terhadap seluruh media sangat ketat, bukan hanya terhadap media yang mendapat dana dari APBN/APBD. Upaya lain pengelola LPPL Radio harus dapat melibatkan publik dan berpedoman pada regulasi penyiaran yang berlaku.

\section{Kesimpulan}

Berdasarkan kajian peraturan dan dengan membandingkan LPPL RRI di atas maka dapat dibuat model Pengembangan LPPL radio sebagai berikut.

1. Dengan persetujuan bersama, Pemerintah daerah dan Dewan Perwakilan Rakyat Daerah membentuk Peraturan Daerah tentang Pembentukan Lembaga Penyiaran Publik Lokal radio sebagaimana dimaksud dalam UU No. 32 Tahun 2002 tantang Penyiaran dan PP No. 11 tahun 2005 tentang LPPL.

2. Peraturan Daerah dijadikan pedoman dalam pembentukan Dewan Pengawas serta pembuatan Peraturan Kepala Daerah tentang 
pedoman penyelenggaran LPPL radio. Peraturan Daerah juga menjadi salah satu syarat untuk memproses ijin siaran melalui Komisi Penyiaran Indonesia Daerah (KPID)

3. Dewan Pengawas membetuk Dewan Direksi sebagai penanggungjawab pengelolaan LPPL radio.

4. Kepala Daerah menerbitkan Peraturan Kepala Daerah tentang Pedoman Penyelenggaraan LPPL radio, yang di dalamnya terdapat penunjukan SKPD atau unit kerja di bawah SKPD sebagai saluran keluarnya anggaran LPPL radio, lengkap dengan kode rekening pengelurannya, serta pedoman pengelolaan keuangan LPPL radio sesuai dengan amanat UU No. 32 Tahun 2002 dan PP No. 11 Tahun 2005, dan Perda tentang LPPL Radio.

5. SKPD pemeritah daerah dimana LPPL Radio berada mengajukan kepada Kepala Daerah untuk menetap LPPL sebagai PKK-BLU.

6. Kepala Daerah dengan Peraturan Daerah menetapkan LPPL sebagai PPK-BLU sesuai peraturan yang berlaku.

7. Dewan Direksi dengan pengawasan Dewan Pengawas menjalankan pelayanan informasi publik secara independen, netral dan tidak komesial sebagaimana diamanatkan UU 32 tahun 2002, dengan memperhatikan dan melibatkan stakeholder yaitu: masyarakat, pengiklan dan pemerintah, sehingga dapat menjadi sebuah taman penyiaran.

\section{Daftar Pustaka}

Banerjee, Indrajit dan Kalinga Seneviratne, AMIC. (2005). Public Service Broadcasting: A best practices sourcebook, First Edition. UNESCO.

Khan, Abdul Waheed. (2006). Public Service Broadcasting in a MultiPlatform World. Dipresentasikan dalam 26th General Assembly of Commonwealth Broadcasting Association (CBA) di New Delhi India, 15 Pebruari 2006.

Mendel, Toby. (2000). Penyiaran Publik: Sebuah Survey Perbandingan Hukum. Singapura: Unesco.

UNDP. (2004). Supporting Public Broadcasting, Learning from Bosnia and Herzegovina's Experience.

Watson, Gregory H. (1996). Strategic benchmarking, Mengukur Kinerja Perusahaan Anda Dibandingkan Perusahaanperusahaan Terbaik di Dunia. Jakarta: PT. Gramedia Pustaka Utama.

Wiratmo, Liliek Budiastuti. (2005). Lembaga Penyiaran Publik Lokal. Semarang: Suara Merdeka.

Wiratmo, Liliek Budiastuti, Noor Irfan, Sigit Wiratmo. (2012). Pengembangan Lembaga Penyiaran Publik Lokal Radio di Jawa Tengah.

When was public broadcasting founded?

http://www.enotes.com/historyfact-finder/ culture-

recreation/when-was-public- 
broadcasting-founded, diakses

25 Mei 2011

http://portal.unesco.org/ci/en/ev.php-

URL_ID $=1525 \& U R L \_D O=D O$

OPIC\&URL

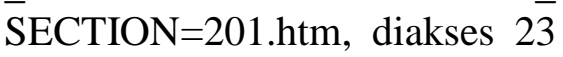

Mei 2011. 